\title{
Betydning og grammatik - i et semiotisk perspektiv
}

\author{
Per Aage Brandt \\ Center for Semiotik, Aarhus Universitet, Danmark
}

Grammar is directly rooted in human phenomenology, in the sense that we all immediately experience the salient and meaningful compositional events in the syntactic structure of currently heard or read texts. Since we have this introspective access to syntax and can grasp the grammatical properties, grammatical analysis can be based on experiential phenomenal composition. I intend to show some basic principles of such an analysis and of a possible graphic form of representation that can work in a pedagogical settting. The structure that appears through long term use of phenomenological and 'stemmatic' analysis of sentence syntax points to the existence of a generic and canonical grammar underlying specific construction grammars; this canonical format is, I suggest to think, rooted in human cognition and its semantic conceptual formats. The article finally presents a text sample from a German newspaper, transcribed according to the stemmatic principles.

\section{Grammatik og fanomenologi}

Lad os indledningsvis betragte det akademiske dilemma: enten er sprogenes grammatiske strukturer kun mekaniske former, der kan betyde hvad som helst eller ingenting, eller også er de identiske med tankens faktiske former og altså fuldt ud betydende. Enten hører grammatikken til på sprogtegnets udtryksside eller på det samme tegns indholdsside. Så enten er grammatikken lige så lineær som det lydlige udtryk eller lige så tredimensionel som tankens mangfoldige billeder. Hvis den er lineær, består den af ordfølger, og man beskriver den ved at nævne de ord, den består af; hvis den er tanken selv, består den af begreber, relationer og billeder, og hver gang vi tænker noget nyt, er grammatikken også ny. I begge tilfælde forsvinder grammatikken som en størrelse, vi kan skelne fra fonetikken og semantikken. Og man kan sige, at disse to tilfælde faktisk blev realiseret, da skolegrammatikken i det 20. århundrede blev til enten generativ linearisme eller kognitiv semantisme.

I mellemtiden er der stadig på alle uddannelsesniveauer blevet undervist i sprog, især fremmedsprog, og denne sprogtilegnelsespædagogik anvender hverken generative eller kognitive metoder, men derimod ganske almindelig sprogbevidsthed hos elever, der er i stand til at læse og forstå en "skolegrammatik" og en undervisning baseret på denne "prælingvistiske" fremstillingsmåde.

Forholdet forekommer mig teoretisk interessant, fordi det understreger en egenskab ved 
sprog, som jeg mener bør bemærkes langt mere end hidtil: grammatisk struktur opleves direkte som meningsfuld af den talende/skrivende eller lyttende/læsende. Fremtidens sprogforskere kunne inddrage dette forhold i selve den begrebslige forståelse af sprog som sådant - at der altså eksisterer en sprogbevidsthed, som kalder på en sprogets fænomenologi.

Vi oplever, at ord i sætninger meningsfuldt lægger sig til andre ord, ofte på tværs af ordfølgen, og at dette påvirker deres betydning væsentligt. Det oplever vi, selv om vore beskrivelser og forklaringer er sparsomme, usikre og endda vildledende. Selve den grammatiske intuition er robust. Dette viser, at vi besidder et mentalt design svarende til opfattelsen af velformede sætningers meningsfulde syntaks. Derfor gælder det for sprogteorien om at finde dette design og om muligt udvikle en konsistent model, der gør "syntaktiske oplevelser" beskrivelige. Når vi er i stand til - i takt med lytning og læsning, dvs. i selve den sproglige udtryksproces' tempo, som vi jo må holde for at kunne forstå, hvad en talende siger, allerede mens han siger det - at organisere den syntaktiske form og dens betydningsindhold så relativt hurtigt og sikkert, kan det kun bero på, at det robuste design for grammatiske strukturer er temmelig enkelt og ensartet, selv om konstruktionerne er meget forskellige. Opgaven for en grammatisk teori er derfor at forstå, hvordan en sætningsorganiserende mekanisme på den ene side kan være enkel og hurtig og på den anden side kan være i stand til at "bære" så vidt forskellige betydninger frem og tilbage mellem mennesker.

\section{SAETNINGERS PROCES OG BETYDENDE FORM}

Hvis vi fremstiller sætningen som en integrationsproces, der sammenfører ord - dvs. ord af enhver ordklasse og indtil den grænse, der adskiller leksemer fra morfemer og her på samme måde syntaks fra morfologi - kan vi forestille os en kaskade af integrationer eller "føjninger", som til sidst, gennem mange trin, fremstiller sætningshelheden. Disse integrationer må være formelt ensartede, og kaskaden må være ordnet, hvis vi skal kunne skabe og opfatte sætninger med denne grad af glat forløbende automatiseret rytmik i højt tempo, som vi kan konstatere hos normale sprogbrugere.

Jeg har foreslået en simpel pseudo-binær bevægelse, der lægger et element til et andet og binder integrationen med et mærke, der fortæller lidt om, hvad der foregår i den. Altså f. eks. (fig. 1):

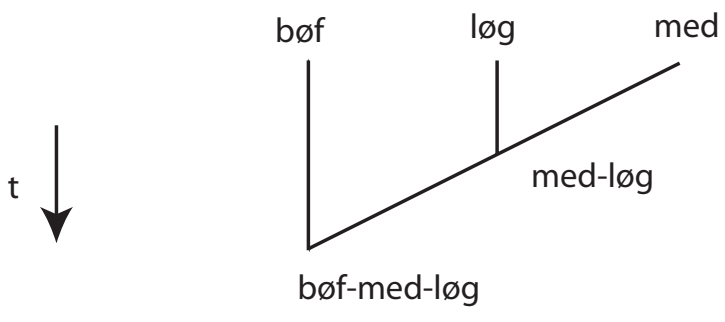

Fig. 1 
Man tager en term ( $b \varnothing f)$ og føjer en anden term $(l \varnothing g)$ til den med et syntaktisk (s) bånd (med). Leddet med-løg giver mere mening end *bøf-med. Min grafik angiver dette tilføjningsprincip, som jeg mener er væsentligt, ved at fremstille integrationen som et asymmetrisk forløb, der gør $l ø g$ til et komplement til $b \varnothing f$ og ikke omvendt og ikke begge dele. Måske er sprogets betydende syntaks opstået i et køkken?

Hvorom alting er, kan denne syntaktiske grundfigur, som jeg kalder en ste $\mathrm{m} m$ at is $\mathrm{k}$ operation, generaliseres, så den bringes til at omfatte hele sætninger og sætningers indgåen i hinanden som led. Vi kan gennemgå princippet i denne generalisering i nogle få trin.

Som Lucien Tesnière (1966) foreslog, kan vi i en sætning skelne mellem en aktantiel del og en cirkumstantiel del. Den aktantielle del vedrører led, der opleves som direkte forbundet med verbets betydning. Den cirkumstantielle del opleves i stedet som forbundet med sætningens betydning.

Lad os først betragte den aktantielle del:

Forholdet mellem verbum og komplementer såsom subjekt, prædikat, objekt, objektsprædikat og indirekte objekt kan opfattes på samme måde. Vi får en lille familie af konstruktioner, der på dansk kunne eksemplificeres som nedenfor (fig. 2) ${ }^{1}$.
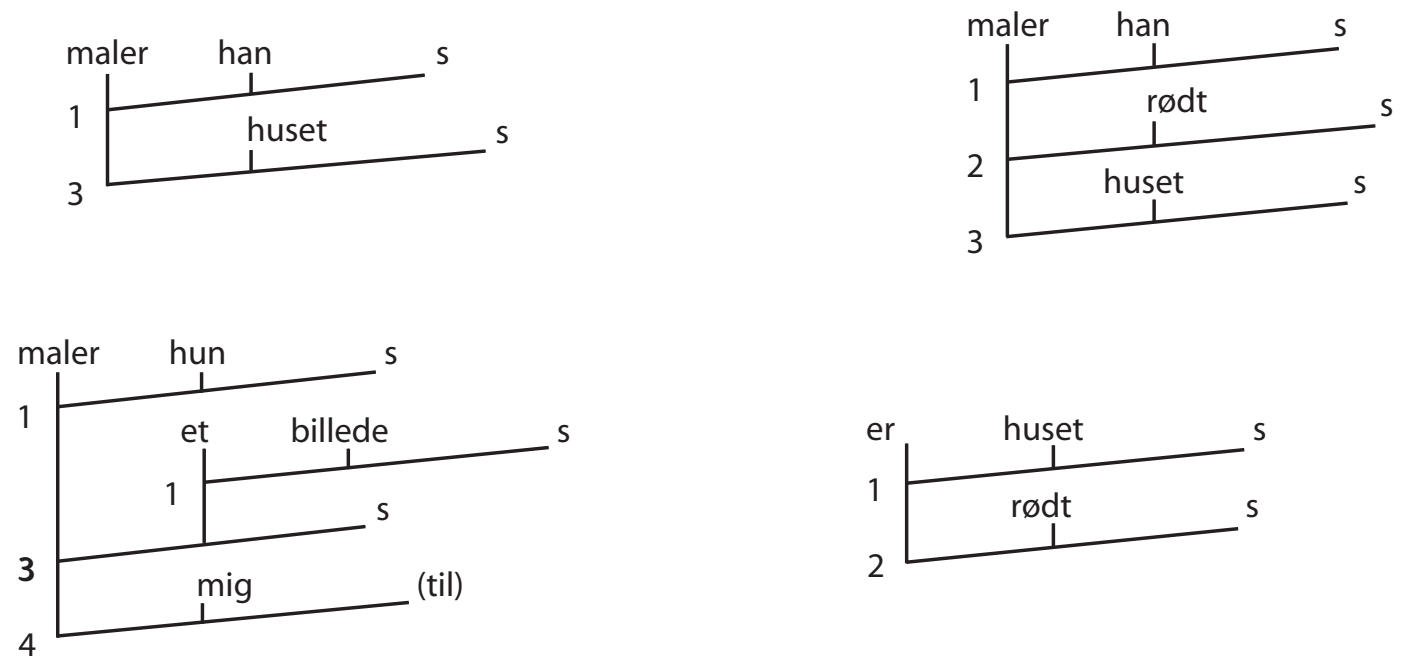

Fig. 2

I denne grafiske model er komplement nr. 1 (C1) det, der føjer subjekt til verbum og frembringer knudepunkt S1. Det næste (C2) føjer prædikat til S1 og frembringer altså 
knudepunkt S2. Hvis vi så har et direkte objekt, dvs. C3, kan vi se, at prædikatet, stadig C2, nu lægger sig til C3 og dermed bliver objektsprædikat. Endelig ville jeg vise, at det indirekte objekt, C4, hægter sig på, så vi får en indholdsmæssig serie C1-4, der er aktantiel. En gang imellem får vi alle fire udfyldt (Jensen ønskede sig bøffen gennemstegt) (fig. 3):

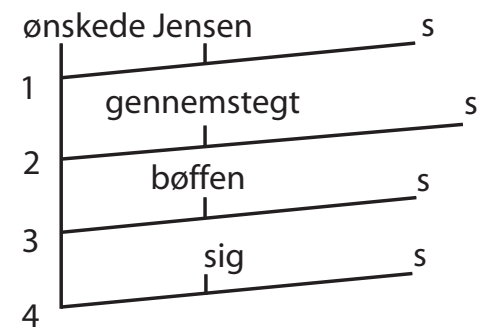

Fig. 3

Jf.: Proesidenten ønskede sig fangen levende. Og lignende konstruktioner.

Konstruktioner kan være meget forskellige, men alligevel være opbygget ifølge det samme princip og endda i den samme meningsfulde aktantielle integrationsorden. Sprogets verber synes født med præferencer for bestemte aktantkonstruktioner, men kan som regel anvendes uden for disse præferencer. Hoste er således et intransitivt, "monovalent" verbum. Men alligevel hostede Jensen sig ind i lokalet (folk veg til side, og han gik lukt igennem mængden takket være sin ildevarslende hoste ...) (fig. 4):

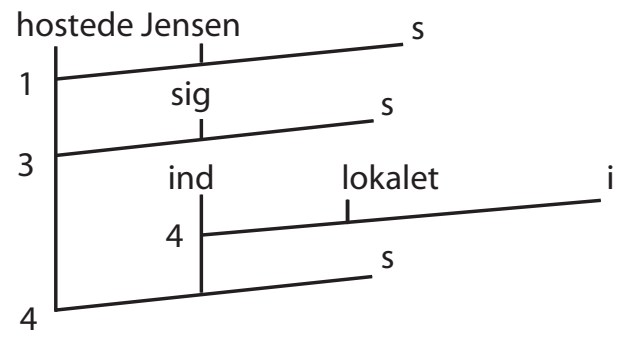

Fig. 4

Her danner C4 samtidig en kaskade (ind $i$... ) af C4-led, der angiver en retning henimod noget, en direktiv betydning. Denne kan være akstrakt som i dativen eller mere konkret som en retning henimod noget i et eller andet rum, som ikke behøver at være fysisk. 
Men lad os gå hastigt videre til den cirkumstantielle del:

Mens C4 som nævnt indfører en retning henimod noget, indfører det følgende led, C5, en retning bort fra noget, altså en projektiv. Denne projektive betydning er i mange sprog markeret af en præposition som med, avec, with, con, cum ... Betydningen kan variere fra in st r u m e $\mathrm{t}$ a $\mathrm{l}$ is (Han slog vinduet $\mathrm{i}$ stykker med sin hammer) over k o $\mathrm{m}$ i t a $\mathrm{t}$ i v (Han gik tur med sin hund) til måden-hvorpå, altså en s t i l i s t i s k cirkumstans (Han sprang over hegnet med elegance). C5 omfatter også passiv agens (Billedet er malet af Jensen). Altså en konstruktion som den følgende (fig. 5):

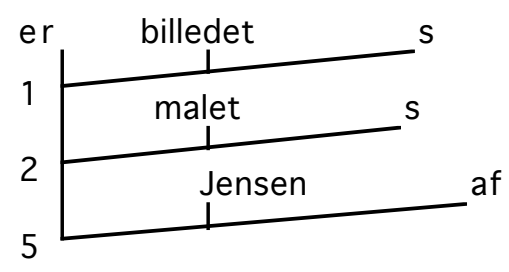

Fig. 5

Det kan være vanskeligt at indse eller acceptere, at alle disse C5-betydninger virkelig lader sig føre sammen; og netop derfor har det været vanskeligt eller snarere umuligt at opstille en sammenhængende kasusteori for sætninger i almindelighed. Men da dette punkt er centralt, kan vi benytte lejligheden til at diskutere det lidt mere. Direktiven, der i øvrigt bruger en række morfemiske verbalsatellitter på germanske sprog (såsom de danske ind, ud, op, ned, hen, frem, bort, hjem ...), kan jo også betyde ganske mange forskellige ting, men alligevel giver det mening at henføre dem under ét til en geometrisk tanke: et noget, der har sit mål i noget andet, som det derfor retter sig imod. Den projektive tanke er da den modsatte: et noget, der udspringer af noget andet, som det dermed kan siges at hidrøre fra eller komme af eller fra (fig. 6): 

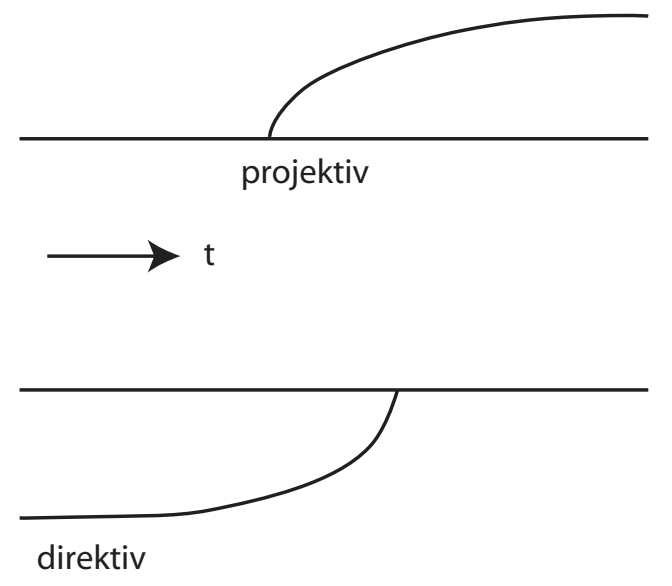

Fig. 6

Disse to skemaer - det direktive og det projektive - leverer ifølge den stemmatiske analyse indhold til C4 og C5, uanset alt, hvad der ellers sker i de specifikke knuder, og som specificerer én projektiv type som stilistisk (Han gjorde det med fornøjelse), en anden som komitativ (Gå med Gud). Og som gør det mærkeligt at sige: Han gjorde det med en hammer og stor fornøjelse ...

De to følgende og sidste komplementer er heller ikke helt enkle at forstå, nemlig lokative n, C6, og det m od a le komplement C7. Når noget sker eller gøres, finder det rigtignok sted i en eller anden ramme, som kan angives lokativisk (Eks.: Han flakkede omkring på Vesterbro) (fig. 7):

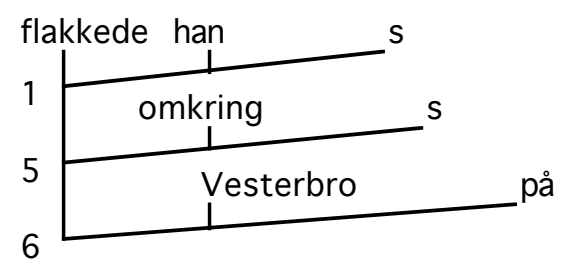

Fig. 7

Mens omkring er en art stilistisk angivelse af en bevægelses krøllethed, altså C5, er på Vesterbro jo lokativisk, C6. Og der er i øvrigt god mening i, at C6 skal følge C5 og ikke 
omvendt; C5 hører stadig til det aktantielle felt, selv om leddet allerede som her kan angive noget, der udfolder sig i rum.

Den vanskeligste detalje er imidlertid den temporale bestemmelses modale status; når vi indfører en tidsangivelse, siger vi også, a t noget er tilfældet, så den temporale angivelse er faktisk også epistemisk modal, den er det modsatte af en negation. Jf.: O m søndagen knuste han tallerkener i Tivoli, over for $\mathrm{O} m$ søndagen knuste han ik ke tallerkener i Tivoli (fig. 8):
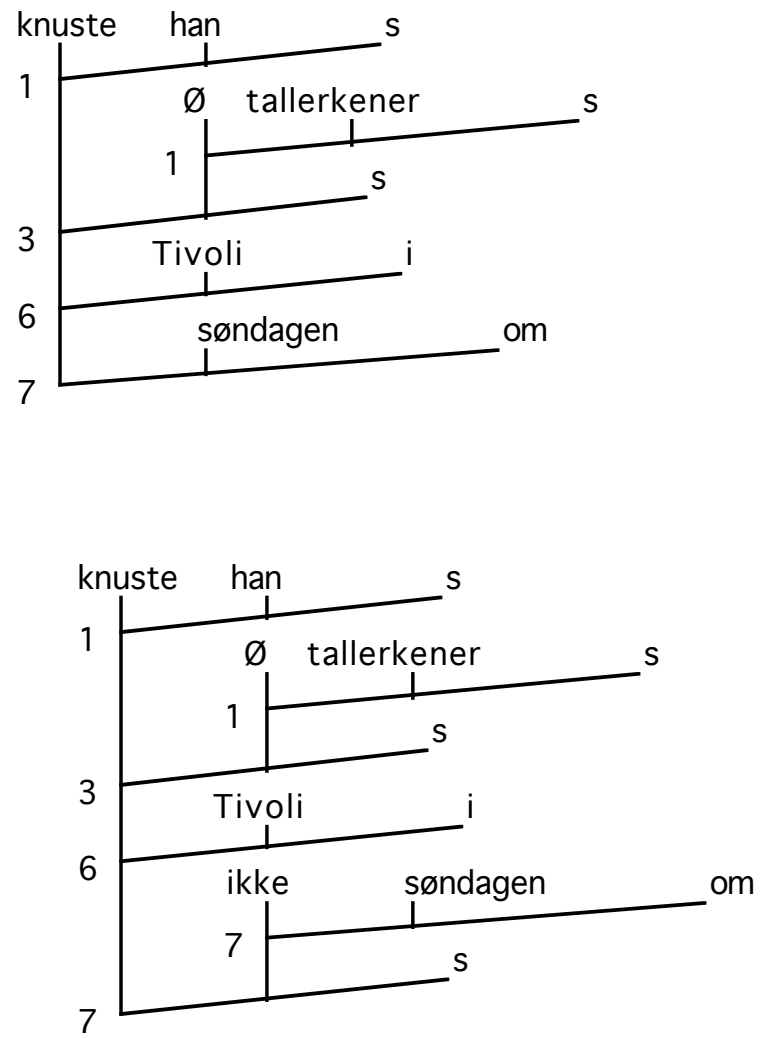

Fig. 8

Han knuste i sidste tilfælde tallerkener i rigelig mængde i Tivoli $^{2}$, bare ikke om søndagen, dvs. kun om søndagen gælder dette ikke. Tidsangivelsen giver gyldighed til negationen. Vi får altså en kaskade i C7, og vi ser her som i ethvert andet temporalt eksempel, hvis vi foretager en passende variation ved hjælp af negationer, at temporaliteten faktisk er en slags affirmation, her enten af en handling eller af en negation af en handling. 
De cirkumstantielle led opfører sig på ganske samme måde i nominalsyntagmer. Jeg har tilladt mig at antage, at nominal determination - ved artikler, ubetonede possessivpronominer og demonstrativer - i sprog, der har en sådan, spiller den samme rolle for nominalled, som verber gør for sætninger. De sætter så at sige et syntagme i gang. Vi får komplekse nominaler såsom (fig. 9):

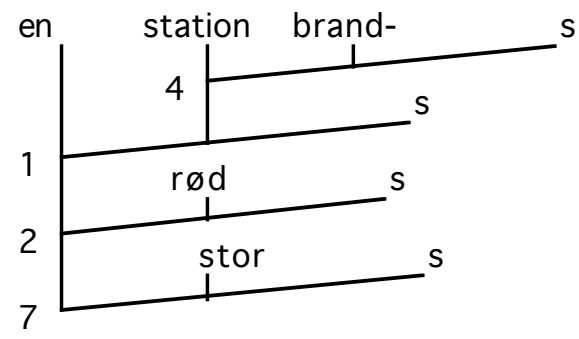

Fig. 9

Station har et internt substantivisk led ('compound'-konstruktion), brand-, der siger, hvad stationen er "til", dvs. specificerer en finalitet. Forskellen mellem rød og stor er, at det sidste adjektiviske led er kvantitetsangivende, hvilket vi kan opfatte som en art modal bestemmelse i nominale sammenhænge. Stor er her beslægtet med rigtig, veritabel, ordentlig osv. Jf. en stor idiot (= en typisk, vaskeægte idiot). Artiklen, inklusive nul-artiklen (Ø), er nominalsyntagmets "hoved", ligesom verbet er verbalsyntagmets "hoved", hvis vi beskriver denne syntaks som 'head-driven'. Forskellen mellem de elementære determinatorer - $\varnothing$, bestemt og ubestemt artikel - er klart semantisk, men jeg skal ikke fordybe mig i denne fascinerende problematik på dette sted. ${ }^{3}$

Hvis vi sætter to sætninger sammen, sker det enten hypotaktisk, ved indlejring, eller parataktisk, ved såkaldt sideordning. I første tilfælde bliver den indlejrede sætning et led i en anden sætning og må altså indtage en komplementplads, nemlig som kompletiv (eks.: at ...), relativ (eks.: som ...), interrogativ (eks.: hvorved ...) eller circumstantiel (eks.: fordi ...) bisætning. ${ }^{4}$

I sidste tilfælde (og, men, for, thi ...) overføres ledbetydninger automatisk mellem sætningerne, som i de følgende sætninger, som ikke skulle være alt for svære at læse (fig. 10): 

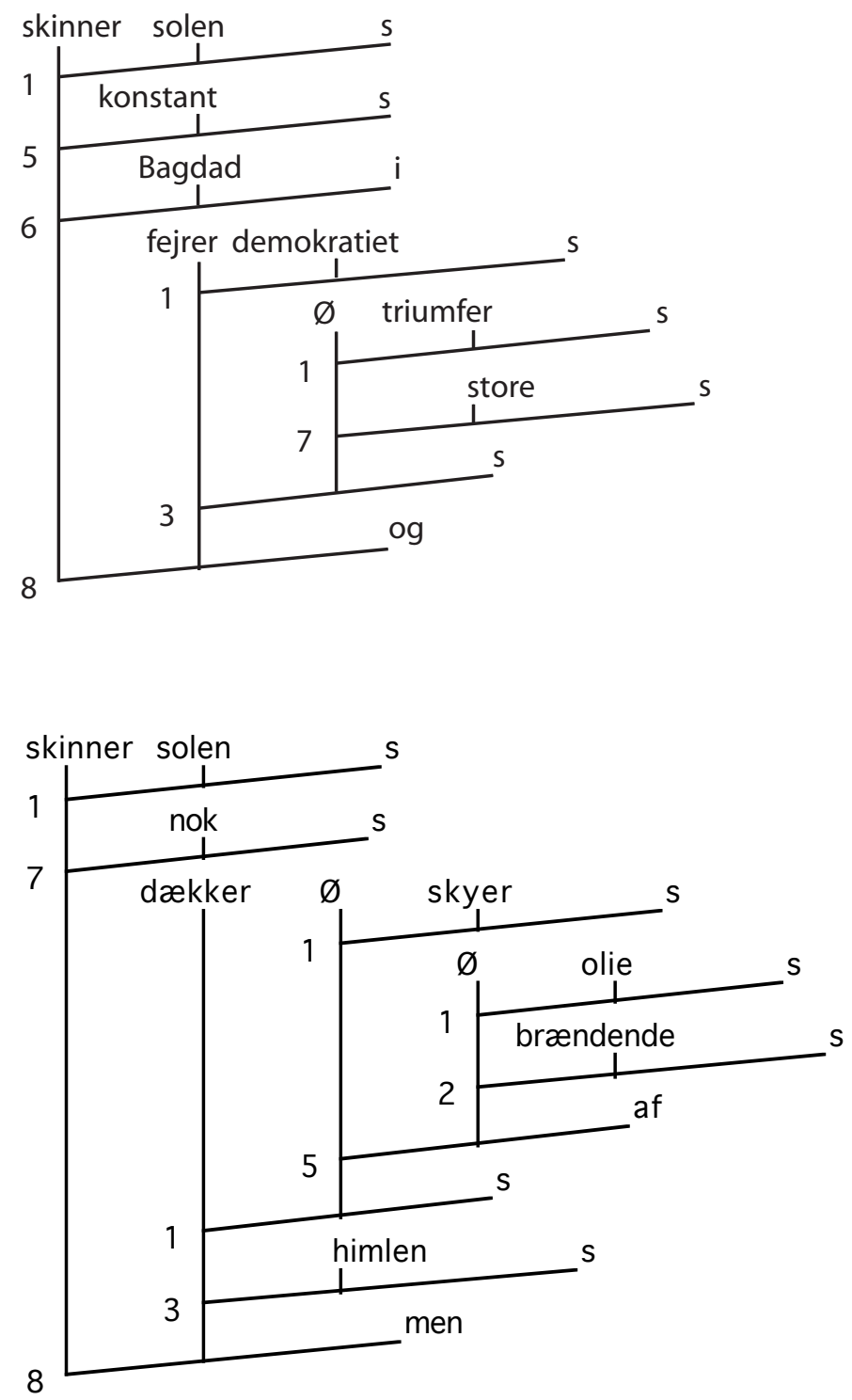

Fig. 10

Lokativbestemmelsens indhold er en geografisk angivelse, der også gælder i C8-leddet efter og. Selv en implicit lokativ overføres - som en forestilling om et konstant rum. Det sker ligeledes ved men. Ved for og thi er der snarere tale om en overføring af C7-indhold, altså epistemisk gyldighed tildelt sætningernes indhold. 


\section{Praktisk eksempel}

Her er en tekst fundet i en avis. Hvis den skitserede analysemåde er holdbar, skal den tillade os at transkribere sammenhængende, empirisk forekommende tekst. Læseren er velkommen til at forsøge for sammenligningens skyld at applicere andre grammatiske teoriers analysemåder på det samme materiale.

\section{ZU GUTER LETZT}

Fünf Stunden lang ist ein Mann splitternackt durch die Strassen der nordostchinesischen Stadt Changchun gerannt. Der Läufer hatte Zuschauer dadurch beeindruckt, dass er den Temperaturen unter dem Gefrierpunkt trotzte und barfuss lief. Nach fünf Stunden Dauerlauf hielt er nicht etwa aus Erschöpfung an, sondern weil eine Polizeistreife ihn stoppte. Die Beamten wickelten den Mann in einen Mantel und brachten ihn in eine psychiatrische Klinik.

Die Welt, 27.11.2003 


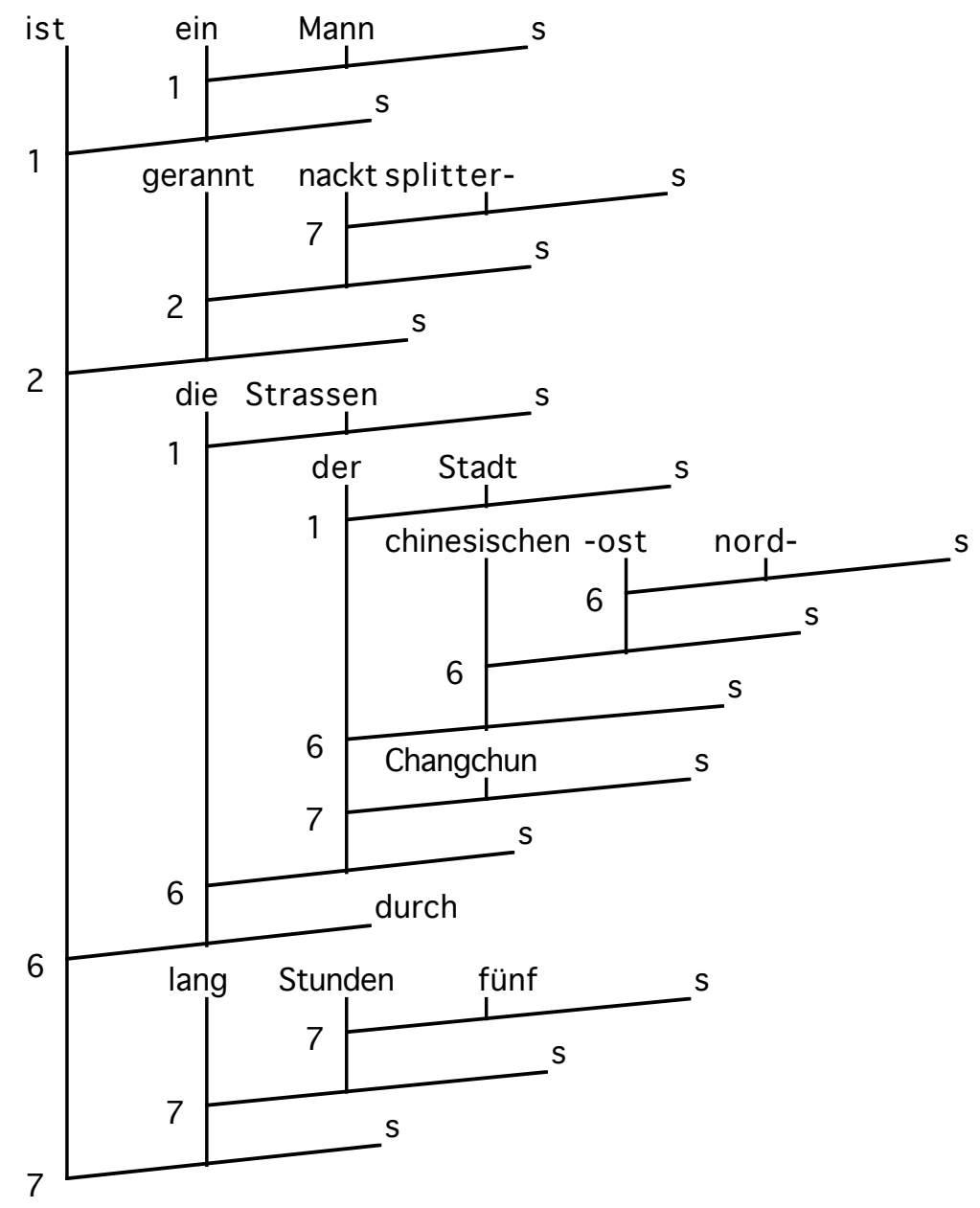

Fig. 11a 


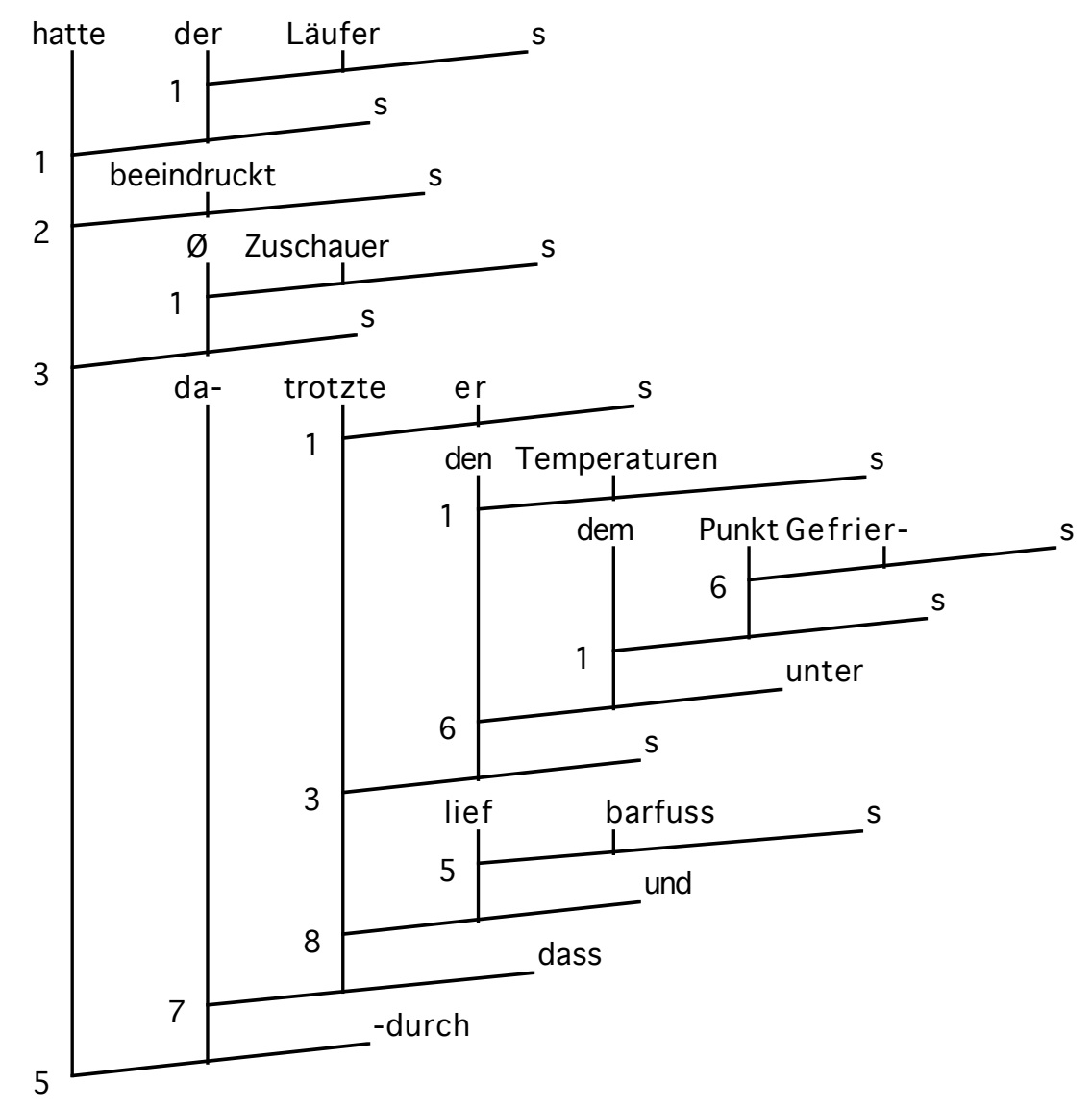

Fig. 11b 


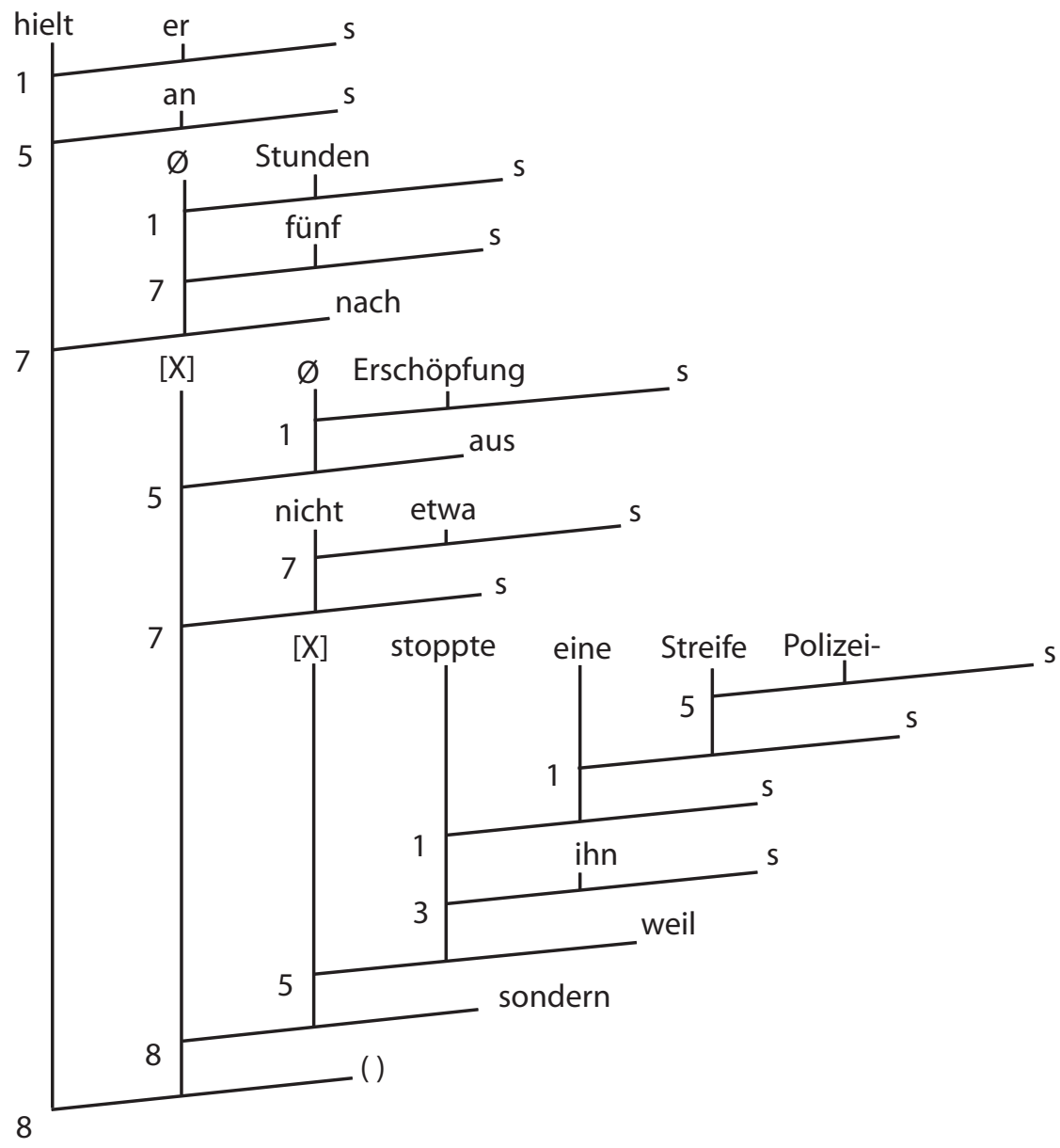

Fig. 11c 


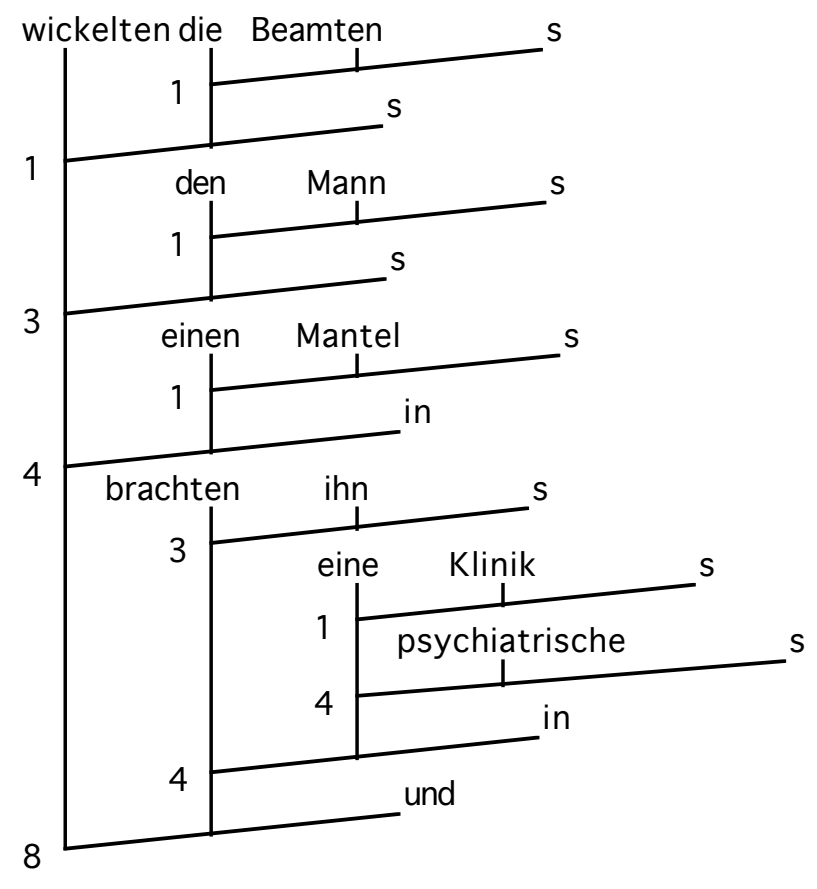

Fig. 11d 
I den første sætning er nordostchinesisch blevet fortolket som et geografisk og derfor lokativisk komplement (C6), og i den sidste sætning er psychiatrisch blevet opfattet som et direktivt komplement (C4), siden klinikkens formål er at dyrke psykiatri og at behandle psykisk syge mennesker. Det er dog et åbent spørgsmål, om adjektiver afledt af nominaler og anvendt i 'compound'-lignende bestemmelsessammenhænge virkelig skal analyseres s å semantisk, eller de stadig blot er prædikativiske attributiver (C2). Det er ikke umuligt, at denne unægtelig fristende praksis fører til nye problemer. I det hele taget vil en analysemåde inden for stemmatikkens rammer stadig (og heldigvis) kunne føre til ret forskellige resultater - hvis respektive gyldighed må afhænge af, om deres generalisering fortsat vil give mening, når den benyttes i nye sammenhænge.

\section{Afsluttende}

Jeg har her sparet læserne for mange enkeltheder ved den fremstillede analysemåde, såsom de koblingsmekanismer, der kendetegner de forskellige former for sætningsindlejring. Min pointe har alene været at vise muligheden af gennem en konsekvent modelanvendelse at iværksætte en beskrivelse af grammatisk struktur såvidt muligt i overensstemmelse med sprogbrugerens grammatiske "fænomenologi", dvs. den umiddelbare oplevelse af denne struktur. Hvis der kan påvises en stabil, intersubjektivt given og for så vidt objektiv struktur i det umiddelbart oplevede, kan dette være af en vis videnskabelig interesse, eftersom det peger på eksistensen af en grammatisk-kognitiv instans i menneskets sproglige kompetence-eller-hvad-vi-nu-skal-kalde-den. Det forekommer mig også i sig selv at være interessant, at man kan skærpe sprogbevidstheden hos mennesker ved at lade en sådan stemmatisk fremstillingsform tjene som spørgeskema ved almindelig sætningsanalyse. Lingvistikken bør i et fænomenologisk-semantisk perspektiv genoptage interessen for det grammatiske som sådant. Det grammatiske er betydende, og det er sikkert netop derfor, det kan udtrykke noget andet betydende: en grammatisk c on st r u c ti o n kan udtrykke en underliggende og i tanken givet construal, vil man nyde at sige på engelsk. Begge instanser, tankens og ytringens strukturer, er betydende, så sprogets betyden kan forstås som en parafrasering af tankens betyden. Tanken kopierer sig selv in d i sproget, når vi udtrykker os. Tanken hentes omvendt u d a f grammatikken, når vi opfatter det, nogen siger, og konstaterer, at det giver mening.

\section{LITTERATURLISTE (SAERDELES SPARSOM)}

Brandt, Per Aage (1973), L'analyse phrastique. Introduction à la grammatique, Bruxelles: AIMAV.

Brandt, Per Aage (2004), Spaces, Domains, and Meaning. Essays in Cognitive Semiotics, Berne: Peter Lang.

Tesnière, Lucien (1966 [1959]), Eléments de Syntaxe Structurale, Paris: Librairie C. Klincksieck. 


\section{NOTER}

1 Grafikken er genereret ved hjælp af programmet Stemmamaker, skrevet til Mac-maskiner; det kan fås via Center for Semiotik, Aarhus Universitet.

2 Sætningen kan ikke betyde, at det ikke var i Tivoli, men et andet sted; negationen samarbejder altså med tidskomplementet, men ikke direkte med stedskomplementet.

3 I sprog som dansk vil bestemt artikel ved nominalet $\mathrm{N}$ tendentielt angive $\mathrm{N}$ som noget, vi tænker på (kvindens voesen); ubestemt artikel ved $\mathrm{N}$ vil angive $\mathrm{N}$ som noget, vi betragter (en kvinde), og Ø ved $\mathrm{N}$ vil angive $\mathrm{N}$ som noget, der føles på en bestemt måde (at vore [Ø] kvinde).

4 Selve indlejringsmekanismen er et særligt studium værd; også her er der finurligheder, der må betragtes nøjere, skønt arten af led vel at mærke svarer til det almene design og komplementernes almene art. 